\title{
Musikale ontlening en die voortbestaan van melodiese spore uit die verlede
}

\author{
H VAN RENSBURG EN BM SPIES ${ }^{1}$
}

\section{Opsomming}

Komponiste kan nie geïsoleer word van die musikale spore van die verlede nie - hierdie spore kan doelbewus deur komponiste betrek word of deur die filter van die onderbewussyn in 'n mindere of meerdere mate in latere werke bly voortbestaan. Dit is moeilik om 'n greep op die verskynsel van musikale ontlening te kry omdat sogenaamde ontlenings nie altyd met voldoende bewysvoering tot die oorsprong teruggevoer kan word nie. In 'n poging om hierdie probleem sistematies te ondersoek, word hier van die standpunt uitgegaan dat daar melodiese gestaltes is wat nie eksklusief aan ' $n$ spesifieke komponis gekoppel kan word nie maar wat deel uitmaak van 'n gemeenskaplike musiekwoordeskat. Een manier waarop helderheid oor hierdie saak verkry kan word, is om 'n historiese benadering te volg deur die spore van melodiese gestaltes in die verlede terug te volg.

Hierdie artikel konsentreer op tematiese spore aangesien melodie daardie aspek van 'n komposisie is wat direk tot die luisteraar spreek. Eerstens betrek 'n historiese perspektief die moontlike bestaan van melodiese spore in die onderbewussyn, melodiese spore as konvensionele figure en die probleem wat ontstaan wanneer ontleende materiaal aan 'n spesifieke komponis gekoppel word. Tweedens word gedemonstreer hoe die melodiese figuur wat begin met die stygende vyfdesprong teruggespoor kan word tot die eerste eeue n.C. 'n Soortgelyke strategie wat die sprong van 'n stygende derde as openingsfiguur betrek, kan hierdie melodiese figuur verder terugspoor, naamlik tot by 'n Griekse Delfiese himne van die tweede eeu v.C.

Trefwoorde: musikale ontlening, melodiese spore, konvensionele melodiese figure, melodiese openingspatrone

Dissiplines: Musiek, Musiekgeskiedenis, Musiekteorie, Etologie, Mnemoniek.

\section{Abstract}

Musical borrowing and the persistence of melodic traces from the past

Composers are not isolated from musical traces of the past - they may use musical ideas deliberately or the traces may filter through their subconscious. The phenomenon of

1 Henriëtte van Rensburg is Senior Lektor in die Skool vir Musiek, Noordwes-Universiteit (jetty.vanrensburg@nwu.ac.za) en Bertha Spies is Buitengewone Professor in Musiek by die Universiteit van Pretoria (spies.bertha@gmail.com). 
musical borrowing is complex, because so-called borrowings cannot always be traced back to their origins with sufficient evidence. In order to approach this problem in a systematic way, we argue that there are melodic patterns which cannot be linked exclusively to a specific composer, but which form part of a common musical vocabulary. One way in which this problem can be resolved is to follow a historical approach by tracing back melodic patterns into the past.

This article focuses on thematic traces, because melody is that aspect of a composition which speaks directly to the listener. Firstly, a historically oriented account examines the possible existence of melodic traces in the subconscious, melodic traces as conventional figures and the problem of attributing borrowed material to a specific composer. Secondly, the article concludes by demonstrating how the melodic figure which starts with the upward leap of a fifth can be traced back as far as the first centuries AD. A similar strategy looking at the opening leap of a third could trace this melodic pattern back to an even earlier Greek Delphic hymn composed in the second century BC.

\section{Executive Summary}

Composers are not isolated from musical traces of the past - they may use existing melodic or other musical structures deliberately or traces of these structures may filter through their subconscious. The phenomenon of musical borrowing is complex because so-called borrowings cannot be traced back to their origins with sufficient evidence. According to J. Peter Burkholder, musical borrowing in Western music is a vast field, the history of which still has to be written (2001:5). In order to approach this problem in a systematic way, we argue that there are melodic patterns which cannot be linked exclusively to a specific composer, but which form part of a common musical vocabulary. This article focuses on thematic traces, because melody is that aspect of a composition which speaks directly to the listener.

A historical approach enables one to find traces of these common melodic patterns in the past, even as far back as Greek antiquity. Peter Burkholder et al. refer to "the debt Western music owes to ancient Greece", as they regard Greek music as the best documented music from antiquity (2010:4). If the cantillation of biblical sections in Jewish synogogues is also taken into account, melodic traces could even be followed further back in time. Although Abraham Idelsohn's research on Jewish cantillation dates back to the early twentieth century, Eliyahu Schleifer regards it as the most important study in its field (2001:47). Idelsohn's research reveals remarkable similarities in the synagogue music of various isolated Jewish settlements in the East, as well as among the older Babylonian and Persian communities and the Moroccan Jews in North Africa (Sendrey \& Norton 1964:265).

In ancient Greek and Roman culture imitating the works of masters formed part of the oratorical tradition (Butcher 1951:1, Murphy 1996:583-5). According to Burkholder, the Gregorian chants of the Middle Ages provide the earliest examples of musical borrowing, because both the new work and its source are notated and can therefore be compared (2001:9). Ernst Klusen mentions the deliberate adoption of certain Gregorian chants by Protestant churches (1958:157). Furthermore, chants were adapted and fragments from these melodies also found their way into the new Protestant repertoire.

In the Renaissance composers did not usually acknowledge the composer from whom musical material was borrowed, because demonstrating skill when reworking material was regarded as more important than creating something new. During the Baroque period it was not regarded as plagiarism when one composer used another's musical 
ideas. However, from the middle of the eighteenth century it became more and more important for a composer to be original, and in the nineteenth and twentieth centuries originality became a prerequisite in judging the musical work of art. By the end of the twentieth century postmodern aesthetics revealed ideological subtexts when a musical work was viewed from a socio-political perspective and the ethics of borrowing African elements for art music, for example, became a contentious matter. However, Kofi Agawu prefers not to focus on the "otherness" of African music, but believes that African and Western music share commonalities. He believes that constructing "African rhythmic patterning as essentially different from that of the West has produced certain myths and misunderstandings" (2003:96).

Standard melodic figures or even longer thematic ideas may be used consciously and deliberately, or they may be perpetuated to a greater or lesser extent through the filter of the subconscious, as the similarity between the main theme of Rachmaninoff's Third Piano Concerto and a Russian chant from the twelfth century demonstrates. Replying to a question on whether this resemblance was intended, the composer emphatically stated that " $t]$ he first theme of my 3rd Concerto is borrowed neither from folk song forms nor from church sources. It simply 'wrote itself! You will probably refer to this as the 'unconscious'!" (Yasser 1969:324-5).

In the seventeenth century direct borrowing became less common and singers, for example, relied on a repertoire of musical figures which they memorised for the purpose of improvisation. Bach and his contemporaries used melodic and rhythmical figures which were widely in circulation, figures which played an important role in the musical rhetoric of the time. However, Imogene Horsley believes that conventional figures can be traced back further into the past, that is to the "vocabulary" of melodic motives of the Gregorian chants of the Middle Ages (2001:99). According to Laszlo Dobszay, melodic physiognomy was more important than specific pitches: "[I]n the centuries prior to the Carolingian fixing of the repertory, the essence of a melody was not so much a defined series of pitches as an abstract melodic structure, i.e. ... the skeleton of motives and melodic lines" (2007:8).

As it is impossible to know all music, one cannot state with sufficient authority who borrowed from whom. For example, Anthony Newmann (1985:154) believes that Bach borrowed his fugue theme of the well-known Toccata and Fugue in D minor, BWV 565, from Pachelbel. However, Dietrich Buxtehude, who was born sixteen years before Pachelbel, also used this as a bass theme. On the other hand, Willi Apel (1972:395) regards the theme from Ricercar del nono tono by Christian Erbach (born 67 years before Buxtehude) as a prototype for the Bach theme. This example shows that the problem of musical borrowing can be partially resolved by working with melodic traces from the past.

In the final section, a melodic figure beginning with the upward leap of a fifth is chosen to demonstrate how a melodic opening pattern can be traced back into the past, using a well-known fugue theme by Bach (BWV 537) as point of departure. According to Richard Hoppin, a number of medieval melodies begin with the dramatic leap of a fifth (1978:75). The fifth degree is also the most prominent reciting note of Gregorian chant (Bailey 2001:454). A melodic pattern, which begins with the leap of a fifth can even be traced back as far as the first centuries AD. The other important reciting note of Gregorian chant, that is the third degree of the scale, produces another melodic opening figure, the upward leap of a third, which could also be traced back into the past, in this case to two restored Delphic hymns of Greek antiquity (second century BC).

The objective of this article is to show how complex the issue of musical borrowing is and that proper reflection is necessary before making simplistic statements about 
borrowing and the influence of one composer on another. A sensitivity to melodic opening figures also helps the listener to follow the temporal unfolding of the music, because the main thematic material recurs most often in the course of a work. If one accepts Agawu's statement, namely that the identification of meaningful units in a composition is the first step in the process of making sense of music (1999:149), then an awareness of melodic opening figures can also help to enhance the understanding of music.

Key concepts: musical borrowing, melodic traces, conventional melodic figures, melodic opening patterns

\section{Inleiding}

Dit is moeilik om 'n greep op die verskynsel van musikale ontlening te kry omdat sogenaamde ontlenings dikwels betrekking het op tematiese materiaal wat nie met voldoende bewysvoering tot die oorsprong teruggevoer kan word nie. ${ }^{2}$ In 'n poging om hierdie probleem sistematies te ondersoek, word hier van die standpunt uitgegaan dat daar melodiese gestaltes is wat nie eksklusief aan 'n spesifieke komponis gekoppel kan word nie maar wat deel uitmaak van 'n gemeenskaplike musiekwoordeskat. ${ }^{3}$ Alhoewel hierdie verskynsel in die literatuur as musikale ontlening beskou word, sou dit help om meer helderheid oor hierdie saak te verkry as mens eerder konsentreer op die verskynsel van musikale spore uit die verlede as op die konsep van ontlening. ' $\mathrm{n}$ Historiese benadering is dus nodig om die spore van melodiese gestaltes in die verlede terug te volg om die aard en die invloed van hierdie spore te probeer bepaal. Die doel van die historiese perspektief is bloot om spore of grepe uit die verlede aan te toon sonder om deurlopende historiese lyne of verbande per se te trek.

$\mathrm{Na}$ ses uitgawes van die hoog aangeskrewe musiekhistoriese bron, A history of western music (D.J. Grout en C.V. Palisca), spreek J. Peter Burkholder in die voorwoord tot die sewende hersiene uitgawe die onderwerp van musikale ontlening direk aan (Burkholder, Grout en Palisca 2006:xxiii-iv). ${ }^{4}$ Op die eerste bladsy van die voorwoord tot die agtste uitgawe verskyn 'n geredigeerde weergawe van dieselfde passasie (Burkholder et al. 2010:xxiii-iv):

It may be surprising that composers from the Renaissance to the twentieth century drew inspiration from ancient Greek music. Or that Bach, Mozart, Beethoven, Brahms, Schoenberg, and many composers living today all borrowed ideas from music written long before they were born. ... It is not that there is nothing new under the sun, but that almost anything new is a fresh twist on what has become traditional. Sometimes what seems newest is actually borrowed in part from music of the distant past.

2 Die doktorale proefskrif van Henriëtte van Rensburg wat sy by die Noordwes-Universiteit onder leiding van Bertha Spies voltooi het, is die uitgangspunt van hierdie artikel. Op grond van hierdie navorsing het sy ook 'n referaat gelewer by die "Ninth international conference on new directions in the humanities" wat by die Universidad de Granada in Spanje gehou is (Junie 2011). 
Musikale ontlening is 'n onderwerp wat talle musiekwetenskaplikes interesseer, soos blyk uit die webtuiste Musical Borrowing wat 'n omvattende alfabetiese lys outeurs met die titels van relevante publikasies bevat (Burkholder 2003). So verskyn daar byvoorbeeld 50 inskrywings onder die letter A alleen, 159 inskrywings onder die letter B en 80 inskrywings onder die letter C. In die beperkte ruimte van 'n artikel is dit dus onmoontlik om werklik reg te laat geskied aan so 'n omvattende onderwerp. Die kwessie van plagiaat, wat die saak nog verder kompliseer, word dus nie hier betrek nie. ${ }^{5}$

Burkholder definieer musikale ontlening as die tegniek om iets uit 'n bestaande musiekstuk te neem en dit dan in 'n nuwe stuk te gebruik (1994:863). Hierdie iets kan wissel van 'n motief, 'n hele melodie of tema, tot langer uittreksels, samestelling van stemme of selfs 'n strukturele plan (Elias 2004:154). Daar is dus verskillende invalshoeke van waaruit die kwessie van musikale spore ondersoek kan word. Hoewel sake soos genre, algemene styl, oorkoepelende ontwerp en instrumentasie ook by die bespreking van musikale ontlening ingesluit word, konsentreer hierdie artikel op die gestalte van tematiek en kleiner melodiese strukture soos patrone en motiewe. ${ }^{6}$

In hierdie artikel sal geargumenteer word dat komponiste nie geïsoleer kan word van die musikale spore van hulle verlede nie en dat sulke spore doelbewus deur komponiste betrek kan word of dat hulle in 'n mindere of meerdere mate deur die filter van die onderbewussyn in latere werke kan bly voortbestaan. Eerstens betrek 'n historiese perspektief die moontlike bestaan van musikale spore in die onderbewussyn, melodiese spore as konvensionele topoï en die probleem wat ontstaan wanneer ontleende materiaal aan 'n spesifieke komponis gekoppel word. ${ }^{7}$ Tweedens word aangetoon dat melodiese openingsfigure teruggespoor kan word tot by melodiese openingsfigure van die antieke Griekse beskawing. Daar word gekonsentreer op die begin van temas omdat die herverskyning van die hoof tematiese materiaal in die loop van 'n komposisie die luisteraar help om die temporele ontplooiing van die musiek te volg.

\section{1. 'n Historiese perspektief}

Volgens Burkholder word bestaande musiek reeds eeue lank deur Westerse komponiste as model vir nuwe komposisies gebruik (1995:12) en Honey Meconi stel dit onomwonde: "Borrowing is probably almost as old as music itself, and Western notated music is replete with examples from every time period" (2004:1). ${ }^{8}$ Hoewel die praktyk van ontlening en die verskynsel van musikale spore in musiek elkeen 'n eie aard mag hê, kan dit teruggevoer word na 'n gemeenskaplike oerpraktyk, naamlik die imitering van navolgenswaardige voorbeelde. Joachim Burmeister eindig sy Musica poetica (1606) wat oor komposisie handel met 'n hoofstuk oor die belangrikheid van

5 'n Gebrek aan sensitiwiteit vir tematiese spore in die letterkunde is moontlik onderliggend aan die aanklag van plagiaat in Sandkastele van André P. Brink (Cloete 2009:9).

6 Die feit dat die melodieleer ' $\mathrm{n}$ verwaarloosde subdissipline van die musiekteorie is, is die uitgangspunt van 'n vorige artikel (Spies 2011).

7 In hierdie artikel word gekonsentreer op die gestalte van temas en motiewe en nie op die betekenis van melodiese figure nie, die onderwerp vir 'n ander studie oor musikale retoriek.

$8 \quad$ Die bespreking van musikale ontlening in die literatuur betrek gewoonlik nie liedere wat in die volksmond bestaan nie. Onder punt 2 hieronder word melodieë uit die antieke Joodse sinagoge-tradisie soos deur Idelsohn opgeteken, asook melodieë uit die antieke Griekse en Romeinse kultuur betrek. 
leer deur middel van imitasie. Volgens Howard Brown is imitering waarskynlik een van die mees algemene gebruike in die kunste en hy meen dat komponiste, net soos skilders en digters, op hierdie manier bedrewenheid in hul vak geleer het (1982:8). ${ }^{9}$

Imitasie van meesterlike voorbeelde is sedert die vroegste tye bekend as deel van die redeneerkuns. Reeds in die antieke Griekse kultuur het Aristoteles se geskrifte oor poëtika die belangrikheid van imitasie beklemtoon (Butcher 1951:1), soos ook Quintilianus se geskrifte oor retoriek in die Romeinse kultuur (Murphy 1996:583-5). Met betrekking tot die vorming van enige ryp, volwasse literêre styl beveel Quintilianus in Boek X van sy Institutio oratoria die volgende aan (Brown 1982:39): "It is from authors worthy of our study that we must draw our stock of words, the variety of our figures and our methods of composition, while we must form our minds on the model of every excellence. For there can be no doubt that in art no small portion of our task lies in imitation."

Gregoriaanse cantus plani $i^{10}$ wat gekomponeer is nadat notasie die repertorium gestandaardiseer het, verskaf volgens Burkholder die vroegste voorbeelde van ontlening waarin beide die nuwe werk en sy bron in notasie vasgelê is en dus vergelyk kan word (2001:9). Komponiste het vanaf die begin van die Hervorming heelwat van hierdie Gregoriaanse kerkliedere aangepas vir gebruik as koraalmelodieë of lofsange in die Protestantse kerke (Burkholder et al. 2010:67). Ernst Klusen maak ook melding van die doelbewuste oorname van sekere Gregoriaanse melodieë of enkele melodiese formules daaruit by die skep van Duitse evangeliese Kerkmelodieë (1958:157). Hy wys daarop dat soortgelyke melodiese formules natuurlik ook elders voorkom, maar angesien die komponiste begin werk het in die oud-kerklike (dit wil sê Rooms-Katolieke) liedpraktyk, reken hy dat die ooreenkomste dáár gesoek behoort te word waar dit vir die komponiste mees toeganklik sou gewees het (1958:159).

In die strewe om geskikte musiek vir hulle eredienste te verskaf, gebruik die Protestantse kerkhervormers in die sestiende eeu dikwels bestaande populêre en sekulêre musiek sowel as ouer gewyde musiek, met verandering van teks waar nodig. Heelwat Lutherse koraalmelodieë is afgelei van tradisionele gewyde sowel as sekulêre melodieë terwyl die Geneefse Psalms ook van populêre chansonmelodieë leen (Picker 2001:369). In sy bespreking van die eerste gedrukte uitgawe van Aulcuns pseaumes et cantiques mys en chant van 1539, wat 19 Psalms en drie Bybelse lofsange (canticles) bevat, wys Pierre Pidoux daarop dat afgesien van die twaalf nuutgekomponeerde melodieë vir die tekste van Clément Marot, die melodieë vir die oorblywende Franse tekste neerkom op die direkte toeëiening van volledige Duitse kerkliedere wat destyds in Straatsburg in gebruik was. Hy verskaf 'n lys van Franse Psalms met hul Duitse melodieë (1956:107-8).

Enkele Geneefse psalmmelodieë is geskep volgens sekulêre voorbeelde, soos byvoorbeeld Psalm 138, wat 'n omvorming van die chanson Une pastourelle gentille is (Pidoux 1955:113-4). Ook die melodie van Psalm 42 is volgens Siegfried Fornaçon nie deur Bourgeois uitgedink nie, maar gebaseer op 'n vyftiende eeuse Franse volkslied, Ne l'oserayje dire. Hy wys verder daarop dat die Bayeux-manuskrip, waarin hierdie volkslied voorkom, 'n hele aantal volksliedere bevat wat met

$9 \quad$ Howard Brown was van 1978 tot 1980 president van die Amerikaanse Musiekwetenskapvereniging.

10 Die uitdrukking "Gregoriaanse cantus planus" dui op die allesomvattende liturgiese repertorium van kerkliedere van die Latynse kerk, vanaf die eerste Christelike eeue, tot by die ordening en vaslegging daarvan onder Pous Gregorius I (ampstermyn vanaf 590 tot 604 n.C.) (Wagner 1986:1). Daarna het dit volgens Wagner na al die Rooms-Katolieke kerke versprei, waar dit tot onlangs nog algemeen gebruik is. 
dieselfde frase begin: F-G-A-G-F-E-D-(C) (1958:112-4). Hierdie melodie van Psalm 42 kom nog steeds in die huidige Psalmboek voor.

Pidoux waarsku egter dat hoewel sekere melodieë van die Hugenote-psalms sedert Orentin Douen se werk in 1878/79 as kontrafakte van sekulêre liedere beskryf is, 'n mens tog versigtig moet wees om, wanneer daar in 'n psalm enkele tone gevind word wat aan 'n melodiese wending in 'n chanson herinner, die afleiding te maak dat die komponis van die psalmmelodie 'n sekulêre voorbeeld gebruik het $(1955: 113)$. Slenk en Luth meen dat sulke ooreenkomste eerder as "idiomatiese toevallighede" beskryf kan word (2001:485), naamlik wat in hierdie artikel beskryf word as musikale spore wat algemeen in omloop was.

In die verwerking van bestaande materiaal het Renaissancekomponiste gewoonlik geen erkenning aan die oorspronklike komponis verleen nie omdat die demonstrasie van vaardigheid in komposisie vir hulle belangriker was (Burkholder 2001:19). Burkholder meen dat eienaarskap van die musiek net so veel, of selfs meer by die gebruiker gelê het as by die oorspronklike skepper daarvan. In die Barokperiode is dit ook nie as plagiaat beskou as komponiste idees by mekaar oorgeneem en verwerk het nie (Harnoncourt 1982:187). Volgens Burkholder was daar verskillende maniere waarop Barokkomponiste van modelle gebruik gemaak het, naamlik vanaf die imitering van 'n algemene styl, tot die verwerking van ' $n$ hele komposisie (1995:12). So het Johann Sebastian Bach (1685-1750) byvoorbeeld instrumentale concerti van Vivaldi (16801743) en Telemann (1681-1767) vir die klawerbord aangepas. 'n Komponis wat veral dikwels by ander komponiste geleen het was $\mathrm{Handel}^{11}$ (1685-1759). Soms gaan sy ontlenings met min verandering gepaard, en ander kere met groter verandering. Die treffende ooreenkoms tussen 'n gedeelte van sy Halleluja-koor uit die Messiah (1741) en Purcell se "Chorus of Devils" uit The Tempest (1695) word byvoorbeeld deur Zimmerman aangetoon (1966:495).

Vanaf die middel van die agtiende eeu het daar egter 'n ommeswaai gekom en dit het vir die komponis al hoe meer noodsaaklik geword om oorspronklik te wees. Die aandrang op artistieke oorspronklikheid het komponiste in die negentiende eeu daartoe genoop om hul musikale "skuldelas" te verbloem (Reynolds 2004:91), want volgens hierdie nuwe opvatting is dit as onoorspronklik beskou om jou eie musiek weer te bewerk, en as plagiaat om van iemand anders te leen sonder om die nodige erkenning te verleen. Skrywers oor musiek onderskryf volgens Burkholder spoedig die aandrang tot artistieke oorspronklikheid (2001:26). Gedurende die laat agtiende eeu is die imitasie van modelle nog steeds beoefen, veral ter wille van opleiding, maar volgens Burkholder was uitgebreide ontlening soos aangetref by Handel of Bach seldsaam onder gevestigde komponiste. Teen die vroeë negentiende eeu was die kenmerk van 'n groot komponis nie meer die vindingryke manipulasie van gegewe materiaal nie, maar veel eerder die uitdink van nuwe melodieë en nuwe effekte. Die negentiende eeu word dus gekenmerk deur 'n toenemende beklemtoning van oorspronklikheid (Burkholder 2001:27). Slegs by die opleiding van jong komponiste was openlike imitasie nog aanvaarbaar.

Die musiekkultuur van die negentiende eeu is volgens Burkholder deur verskeie strominge dramaties verander (2001:29). Eerstens is die komponis gesien as 'n kunstenaar en nie meer as 'n vakman nie. Verder het daar 'n splitsing gekom tussen kunsmusiek en populêre musiek. ${ }^{12}$ Daar

11 Hoewel Handel in Duitsland as Händel gebore is, word die Engelse spelling hier gebruik aangesien hy sy merk as komponis gemaak het terwyl hy in Engeland werksaam was.

12

By gebrek aan 'n beter term, word "kunsmusiek" gebruik om te verwys na wat in die omgangstaal as "klassieke musiek" bekend staan. Die probleem met "kunsmusiek" is dat die term die eksklusiwiteit van TD, 7(1), Julie 2011, pp. 1- 24. 
was ook 'n groter neiging as ooit tevore om eienaarskap van 'n musiekwerk aan die betrokke komponis toe te skryf, en oorspronklikheid het steeds in belangrikheid gegroei.

Die twintigste eeu word ook gekenmerk deur 'n toenemende beklemtoning van oorspronklikheid in kunsmusiek. Lawrence $\operatorname{Kramer}^{13}$ wys daarop dat die hoogmodernistiese ideaal van oorspronklikheid aanleiding gegee het tot die idee dat om absoluut modern te wees, “... one must be difficult, off-putting, esoteric...The public, the so easily vilified bourgeois public, is excluded from listening, by a cult of enhanced difficulty and esoteric order" (2002:269, 267). Die ignorering van musiekspore uit die verlede het dus ook aanleiding gegee tot kwynende konsertgehore en die kultus van oorspronklikheid, soos dit deur die hoogmodernisme bevorder is, het volgens Kramer uiteindelik die doodsklok vir klassieke musiek gelui (2002:271).

Aan die ander kant is dit volgens Burkholder tog merkwaardig hoe dikwels twintigste-eeuse komponiste steeds bestaande musiek in hulle werke inkorporeer (2001:29). In musiek begin die praktyk van aanhaling ("Zitatpraxis") om en by 1900 toeneem (Gruber 1998:2406) en in die tweede helfte van die twintigste eeu word intertekstualiteit 'n belangrike onderwerp van besinning in literêre kritiek. 'n Sensitiwiteit vir reeds bestaande tekste, al was dit in die onderbewussyn, kon Steven Greenblatt genoop het om te skryf dat

\begin{abstract}
despite our romantic cult of originality, most artists are themselves gifted creators of variations upon received themes. Even those great writers whom we regard with special awe, and whom we celebrate for their refusal to parrot the clichés of their culture, tend to be particularly brilliant improvisers rather than absolute violators or pure inventors (1995:239).
\end{abstract}

In Suid-Afrika het die praktyk van aanhaling ook inheemse Afrikamusiek betrek, soos byvoorbeeld die gebruik van die Zululied Shosholoza in Hans Roosenschoon se Makietie vir koperblaaskwintet. Dit is die eerste maal in 1978 in Londen uitgevoer. Afrika-elemente is ook deur verskeie ander Suid-Afrikaanse komponiste, soos byvoorbeeld Peter Klatzow, Jeanne Zaidel-Rudolph en Hans Huyssen betrek. Die komponis wat waarskynlik die bekendste is vir sy musikale verbintenis met die land waarin hy woon, is Stefans Grové wat tans besig is met no. 38 in sy Afrikareeks. ${ }^{14}$

Die postmoderne estetika het in die laaste dekade van die twintigste eeu aanleiding gegee tot die beoordeling van die musiekwerk vanuit 'n sosiaal-politieke oogpunt en so is ' $n$ ideologiese subteks onderliggend aan die gebruik van Afrika-elemente blootgelê. Hierdie benadering het ' $n$ debat oor die etiese regverdigbaarheid van kulturele toeëiening ingesluit, 'n debat wat steeds nie afgehandel is nie. Westerse komponiste is daarvan beskuldig dat hulle die Afrikakultuur ter wille van politieke korrektheid vir eie gewin eksploiteer of selfs plunder. Chris Walton verwys onder andere na sekere blanke Suid-Afrikaanse komponiste se "hasty and demonstrative adoption of the

hierdie tipe musiek versterk. Dit beteken dus dat hierdie gewaande ontoeganklikheid nie in pas is met postmoderne ideale nie. se hoofstuk oor Grové se pad van Bethlehem (sy geboortedorp) na Damaskus (Muller \& Walton 2006). 
ideals and policies of the ANC (their haste being often in direct proportion to their complicity with the previous regime)" (2006:67). In antwoord op Christine Lucia se skerp kritiek (1993:117), wys Peter Klatzow daarop dat hy reeds op dertienjarige ouderdom (in die vyftigerjare) Nkosi Sikelel' iAfrika as klimaks van die koraalfinale in sy eerste poging vir orkes ('n simfonie) gebruik het. Hy noem onder andere ook dat die koorgedeeltes van sy toonsetting van Eugene Marais se Dans van die reën (1963) beïnvloed is deur die kore wat hy in Swaziland gehoor het terwyl hy daar gewerk het (1994:125). Verder onthou Stefans Grové nog hoe hy as kind buite saam met die skoonmakers gesing het nadat hulle klaar gewerk het in die seunskoshuis wat deur sy ouers bestuur is. Hy meen dat sulke ondervindings 'n voorbereiding was, al was dit onbewustelik, vir die musikale terugkeer tot sy Afrikaherkoms in die tagtigerjare (Walton 2006:67)..$^{15}$

Die ontlening van Afrika-elemente is egter 'n meer komplekse saak as wat dit op die oog af lyk. Die neiging om byvoorbeeld sekere musikale ritmes as tipies van Afrika te beskryf, is sterk gekritiseer deur Kofi Agawu, 'n boorling van Ghana en tans professor in Musiekteorie en Musieketnologie aan die Universiteit van Princeton: "The eagerness to construct African rhythmic patterning as essentially different from that of the West has produced certain myths and misunderstandings" (2003:96). Sogenaamde tipiese Afrika-elemente soos ostinaatpatrone (ritmiese en melodiese patrone wat oor en oor herhaal word) en melodieë en motiewe wat gebaseer is op die pentatoniese toonleer (soos C,D,E,G,A) is byvoorbeeld ook algemeen in Westerse musiek. Ravel se Bolero met sy herhalende ritmiese en melodiese patroon wat na 'n groot klimaks opbou, is waarskynlik meer bekend as die talle voorbeelde van Barokorrelwerke (soos die Passacaglia-genre) wat op herhalende baslyne en gepaardgaande ooreenkomstige harmoniese strukture gebaseer is. Pentatoniese melodiese strukture kom ook in ander lande se volksmusiek voor en wat kunsmusiek betref, dink 'n mens dadelik aan die openingsfrase van "Oggend" uit Grieg se Peer Gynt Suite.

Vir Agawu hou die oormatige beklemtoning van andersheid negatiewe gevolge in (2003:168-9, 196-7):

\begin{abstract}
If differencing has produced such distorted, ideologically one-sided, and politically disadvantageous representation, and if a reasonable proposition to fuse horizons fails to overcome its core difficulty, why not eliminate it altogether and substitute a carefully defined sameness?... Let us, therefore, get away from simple binary divisions of the world, the cultism that wishes to see a categorical difference between Western knowledge and African knowledge.
\end{abstract}

Hy onderskei egter tussen inherente andersheid ("ineradicable difference enshrined in the very act of representation") en 'n konstruksie van andersheid wat ideologies gedrewe is (2003:95-6). Deur nie net te konsentreer op die "andersheid" van Afrika-musiek nie ${ }^{16}$ en deur te erken dat Afrikamusiek en Westerse musiek wel gemeenskaplikhede het, kan die ruimte tussen andersheid en eendersheid produktief benut word deur ook op Westerse analitiese en interpretatiewe strategieë te steun $(2003: 171,197)$.

Grové het in 1972 na Suid-Afrika teruggekeer nadat hy 15 jaar in Amerika was.

"It is time to shun our precious Africanity in order to participate more centrally in the global conversation" (Agawu 2003:171).

TD, 7(1), Julie 2011, pp. 1- 24. 


\subsection{Musikale spore in die onderbewussyn}

Walter Jost en Michael Hyde glo dat ons hede met die verlede beklee is (1997:xv). Musikale spore en musikale ontlening kan dus beskou word as manifestasies van 'n historiese bewussyn. Johann Tempelhoff meen dat elkeen van ons oor 'n bewussyn van die verlede beskik en beskryf historiese bewussyn as 'n "breë stroom van werklikheidsbesef wat nie noodwendig self deurleef is nie" maar waarvan die mens tog in 'n mate bewus is $(2002: 11,138)$. Daarvolgens dra ons voortdurend, bewustelik of onbewustelik, een af ander vorm van geskiedenis met ons saam.

Joseph Yasser meen dat die komponis nie noodwendig self bewus hoef te wees van die invloed van musikale spore uit die verlede nie. Volgens Yasser is hierdie musikale spore veral merkbaar in die wyse waarop die komponis sy melodiese materiaal fatsoeneer. Vervolgens beskryf hy hoe hierdie proses van onbewustelike ontlening moontlik kan verloop (1969:313-4):

Imagine that a composer hears an unfamiliar piece of music and is impressed by one of its thematic constructions. Such an impression would usually be retained for some time in his conscious memory, with some portions of it remaining much longer than the others. Usually, however, the original conscious impression gradually fades and slips into the subconscious depths of his musical mind. There this semiforgotten material lies dormant for an unspecified time - from months to years - but, like decaying organic material, it begins to split into smaller components, that is individual phrases and subphrases, motivic bits, fragmented curves of the basic Urlinie with their characteristic rises, falls, etc.

Met verloop van tyd mag die omgekeerde prosedure hiervan in die komponis se onderbewussyn plaasvind deur onbewustelik die musikale materiaal wat in die onderbewussyn gebêre is, te integreer. Hierdie integrasie van musikale materiaal kan gepaard gaan met veranderings en byvoegings.

Hoe hierdie proses van onbewustelike ontlening kan verloop, word deur Yasser (1969:315 e.v.) geskets in sy bespreking van die ooreenkoms tussen die openingstema van Sergei Rachmaninoff se Derde Klavierkonsert met 'n antieke kerklied van die Russies Ortodokse kerk. Volgens hom moes dit die ontstaan van die Rachmaninoff-tema beïnvloed het deurdat hierdie ou Russiese cantus planus ("chant") in Rachmaninoff se onderbewussyn kon gewees het. Hierdie Russiese kerklied dateer uit die twaalfde eeu, en vóór dit uit mondelinge oorlewering van die antieke Griekse repertorium.

\section{Voorbeeld 1a: Rachmaninoff, Derde Klavierkonsert, opening}

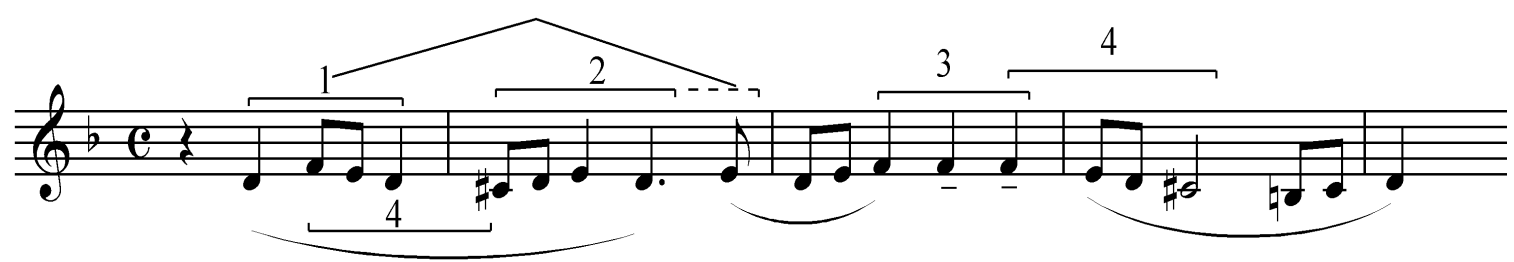




\section{Voorbeeld 1b: Antieke Russiese cantus planus, opening}

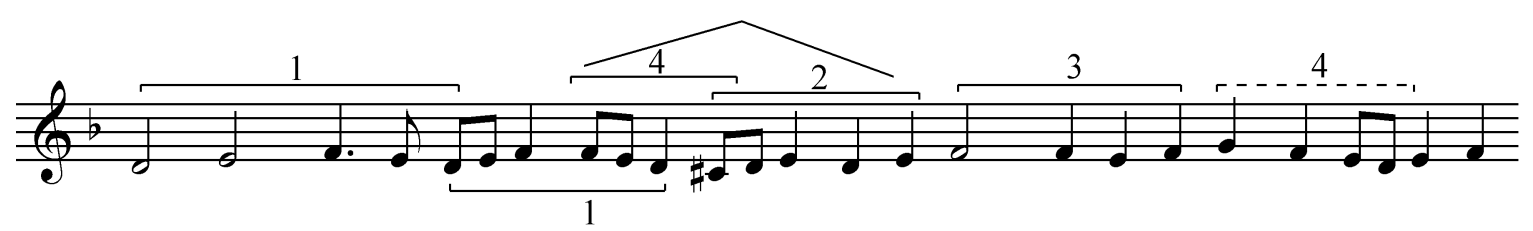

Daar is 'n merkwaardige ooreenkoms tussen die opening van die ou Russiese kerklied en die opening van Rachmaninoff se Derde Klavierkonsert. ${ }^{17}$ Die sprong tussen die eerste twee note van Rachmaninoff se tema is die buitelyn (D-F) van die eerste cantus planus-motief waar dit trapsgewys beweeg vanuit $\mathrm{D}$, deur die deurgangsnoot $\mathrm{E}$, om by $\mathrm{F}$ uit te kom. In die middel van voorbeeld $1 \mathrm{~b}$ dui die spitshakie 'n langer melodiese fragment aan wat na die begin van die Rachmaninoff-tema verskuif het.

In 'n persoonlike brief aan Rachmaninoff vra Yasser (1969:324-5) of hierdie betrokke tema bewustelik ontleen is aan Russiese nasionale bronne, hetsy liturgies of sekulêr, waarop Rachmaninoff ontkennend antwoord: "The first theme of my $3^{\text {rd }}$ Concerto is borrowed neither from folk song forms nor from church sources. It simply 'wrote itself! You will probably refer to this as the 'unconscious'!"

\section{$1.2 \quad$ Musikale spore as konvensionele topoï}

In die sewentiende eeu het direkte ontlening verminder en het konvensionele patrone en figure sterker op die voorgrond getree (Burkholder 2001:22). In hierdie eeu het sangers 'n repertorium van melodiese figure van buite geleer. Die sangers het ter wille van improvisasiegebruik hierdie melodiese figure gememoriseer sodat hulle dit, indien nodig, beskikbaar sou hê vir gebruik in spesifieke kontekste (Collins \& Carter 2001:104).

Bach en sy tydgenote het gebruik gemaak van melodiese en ritmiese figure wat algemeen in omloop was. Ellen Harris meen dat heelwat van die sogenaamde "ontlenings" in Handel se musiek eintlik sulke konvensionele figure is wat algemeen in gebruik was (1990:304). Hierdie figure het ook 'n belangrike rol gespeel in die studie van die musikale retoriek van die tyd, die onderwerp van Praecepta der musicalischen Composition (1708) en Musicalisches Lexicon (1732) van Johann Gottfried Walther asook Thomas Bakhasar Janowka se Clavis ad thesaurum magnae artis musicae van 1701 (Clark \& Peterson 1984:15). In die Leipziger Allgemeine Zeitung van 1800 word melding gemaak van "die oorname van musikale periodes, wat eenvoudig as algemene gebruiksgoed beskou moet word, waarvan die gebruik enige iemand vry staan” (Gruber 1998:2402)..$^{18}$

Imogene Horsley meen egter dat konvensionele figure nog verder terug in die verlede gevind kan word, naamlik in die "woordeskat" van melodiese motiewe in die kerklied (cantus planus) van die Middeleeue (2001:99). Hierdie Middeleeuse komposisiemetode wat 'n sintese van

\footnotetext{
17 Om vergelyking te vergemaklik, is die Russiese kerklied na dieselfde toonsoort (D mineur) as die Rachmaninoff-tema getransponeer.

18 "Übernahme von musikalischen Perioden, die man schlechterdings als Gemeingüter ansehen mu $\beta$, deren Gebrauch jedem frey steht."
} 
voorafbestaande musikale eenhede behels, staan bekend as sentonisasie (Chew \& McKinnon 2001:356). 'n Melodie in 'n spesifieke modus, soos die Doriese modus, maak byvoorbeeld dikwels gebruik van dieselfde, of 'n soortgelyke, "woordeskat" van melodiese motiewe. Verder was hierdie kerkliedere wat gedurende die negende eeu genoteer is musiek wat reeds vroeër in die praktyk geleef het, en deur middel van 'n mondelinge tradisie in die geheue behou is (Dobszay 2007:3). Vir Laszlo Dobszay was die melodiese gestalte meer belangrik as spesifieke toonhoogtes:

[I]n the centuries prior to the Carolingian fixing of the repertory, the essence of a melody was not so much a defined series of pitches as an abstract melodic structure, i.e. ... the skeleton of motives and melodic lines (2007:8).

\subsection{Kan die oorsprong van ontleende materiaal bepaal word?}

Algemeen gesproke maak musiek gebruik van die beskikbare poel van note, toonlere, ritmes, figure en ander elemente wat eie aan 'n spesifieke tradisie is (Burkholder 2001:5). Aangesien dit onmoontlik is om alle musiek te ken, is dit nie moontlik om met sekerheid uitsprake te maak oor wie by wie "geleen" het nie. Anthony Newmann, kenner op die gebied van Barokuitvoeringspraktyk, beweer byvoorbeeld dat Bach sy fugatema uit die bekende Toccata en Fuga in D mineur, BWV 565, ${ }^{19}$ van Pachelbel (1653-1706) oorgeneem het (1985:154).

\section{Voorbeeld 2a: Bach, Toccata en Fuga in d, BWV 565, fugatema, mate 30-32}

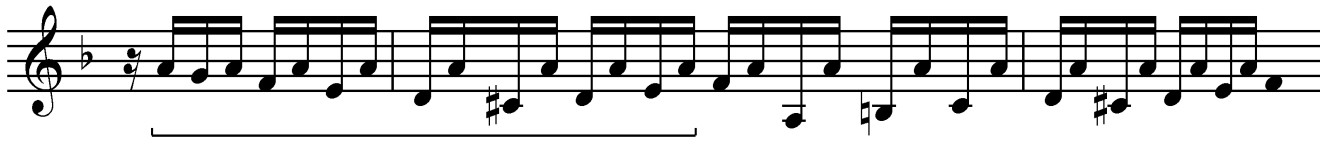

\section{Voorbeeld 2b: Pachelbel, Fantasie in d, maat 32}

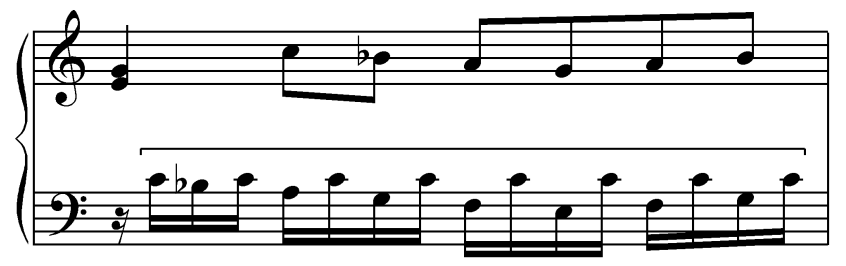

19 Uit Bach (1964). Bach se outeurskap van hierdie werk word sedert 1980 deur sommige musiekwetenskaplikes bevraagteken (Jones 2007:viii). Van voorbeeld 2 af word die bronne van die notevoorbeelde in voetnote aangegee aangesien die talle verwysings binne in die teks dit moeilik maak om die argument te volg. 
Dietrich Buxtehude (1637-1707), wat sestien jaar voor Pachelbel gebore is, het egter ook so 'n opening vir 'n pedaaltema gebruik. ${ }^{20}$

Voorbeeld 2c: Buxtehude, Prelude in d, BuxWV 140, mate 4-5

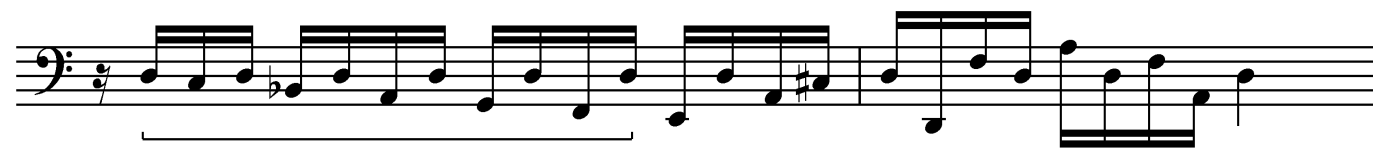

Aan die ander kant beskou Willi Apel weer Christian Erbach (wat 67 jaar voor Buxtehude gebore is) se tema van sy Ricercar del nono tono as 'n prototipe van bostaande tema van Bach (1972:395). Die verkleining van die tema wat later in die werk voorkom (voorbeeld 2e), toon merkwaardige ooreenkomste met die opening van Bach se fugatema.

\section{Voorbeeld 2d: Erbach, Ricercar del nono tono}

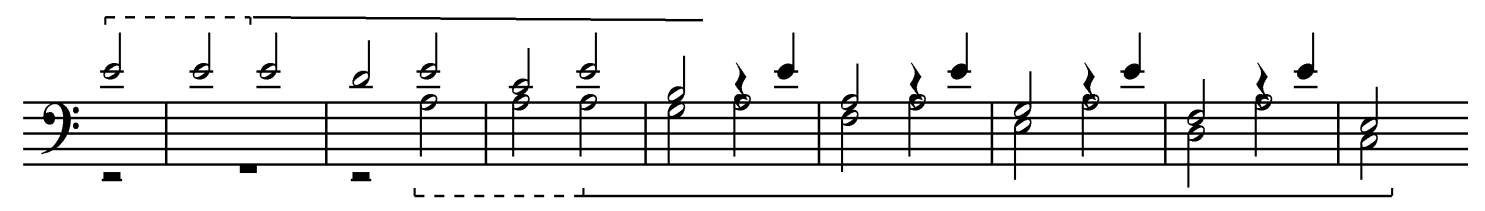

\section{Voorbeeld 2e: Erbach, Ricercar del nono tono, maat 32}

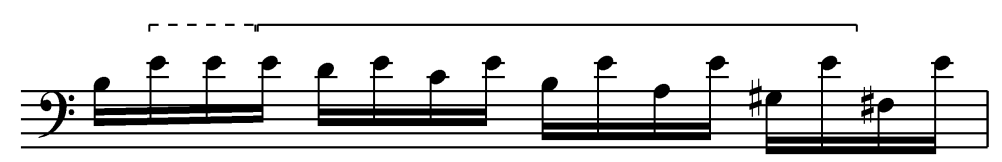

Aangesien dit dus nie moontlik is om met sekerheid te besluit van wie Bach hierdie tema geleenn het nie, is dit veiliger om te sê dat die ooreenkomste wat deur 'n historiese terugkyk op die verlede opgelewer word, eerder dui op die teenwoordigheid van musikale spore uit die verlede.

\section{Terugsporing van 'n melodiese openingsfiguur}

Aangesien die Barokperiode veral 'n tydperk was waarin standaardfigure 'n belangrike rol gespeel het, is ooreenkomstige tematiek in die vrye orrelwerke van die bekende komponiste Bach en Buxtehude in ' $\mathrm{n}$ uitgebreide studie as uitgangspunt geneem (Van Rensburg 2010). Na aanleiding van die resultate van hierdie studie is die ooreenkomstige melodiese openingspatrone weer as uitgangspunt geneem om soortgelyke openingspatrone verder in die verlede terug te spoor. Hier is dus nie soseer sprake van ontlening nie maar eerder die uitwys van ooreenkomstige figure op 'n belangrike plek in die melodie, naamlik die begin. 
Ten slotte sal een spesifieke melodiese openingsgestalte tot sover as die Romeinse beskawing teruggespoor word. Dieselfde strategie met ' $\mathrm{n}$ ander melodiese openingspatroon, spoor melodiese figure so ver terug as die Griekse Delfiese himnes wat ter ere van Apollo in die tweede eeu voor Christus gekomponeer is. ${ }^{21}$

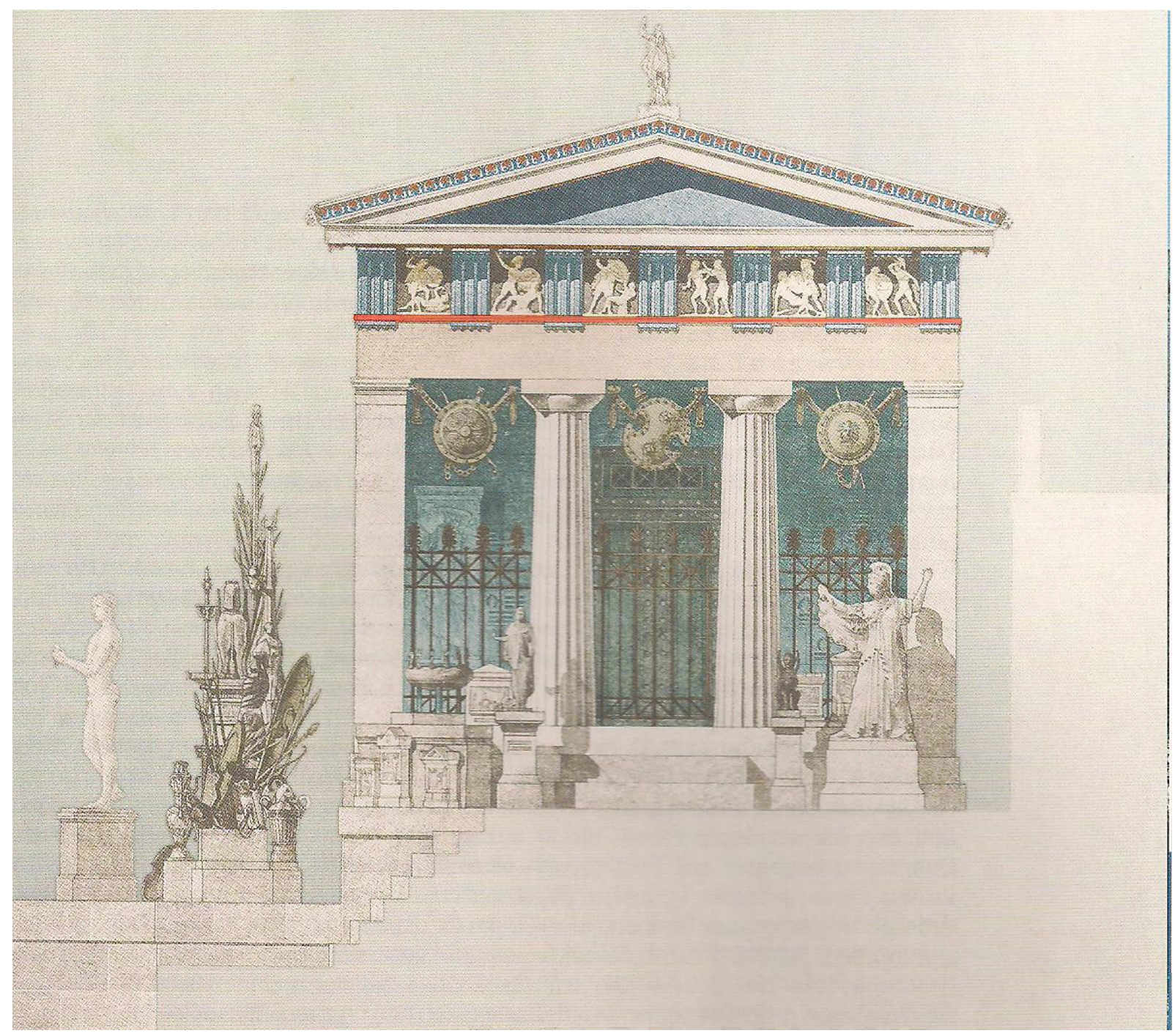

\section{Illustrasie 1: Rekonstruksie van die Atheense skatkamer (Petsas, 2008:45)}

Burkholder et al. verwys na " ... the debt Western music owes to ancient Greece ... " en beskou die Griekse musiek as die bes gedokumenteerde musiek uit die antieke tradisie (2010:4). Musikale spore sou selfs verder as die antieke Griekse beskawing teruggevolg kon word indien die kantillering van Bybelgedeeltes in die Joodse sinagoge ook verreken sou word. Die navorsing van Abraham Idelsohn, die eerste moderne geskiedskrywer oor Joodse musiek (Braun 1996:1514) word deur Schleifer as die belangrikste moderne studie oor die onderwerp beskou, hoewel dit reeds in die vroeë 1900s gedoen is (2001:47). ${ }^{22}$

$21 \quad$ Weens beperkte ruimte kan slegs enkele voorbeelde uit die musiekgeskiedenis hier aangehaal word. Kyk Van Rensburg (2010) vir verdere voorbeelde.

22 Idelsohn het oor 'n hele aantal jare mondeling oorgelewerde Hebreeuse melodieë uit verskillende afgeleë Joodse nedersettings versamel, vergelyk en ontleed. Die navorsing wat tussen 1914-1932 in tien bande gepubliseer is as Hebräisch-Orientalischer Melodienschatz sluit altesaam 3775 melodieë in. 


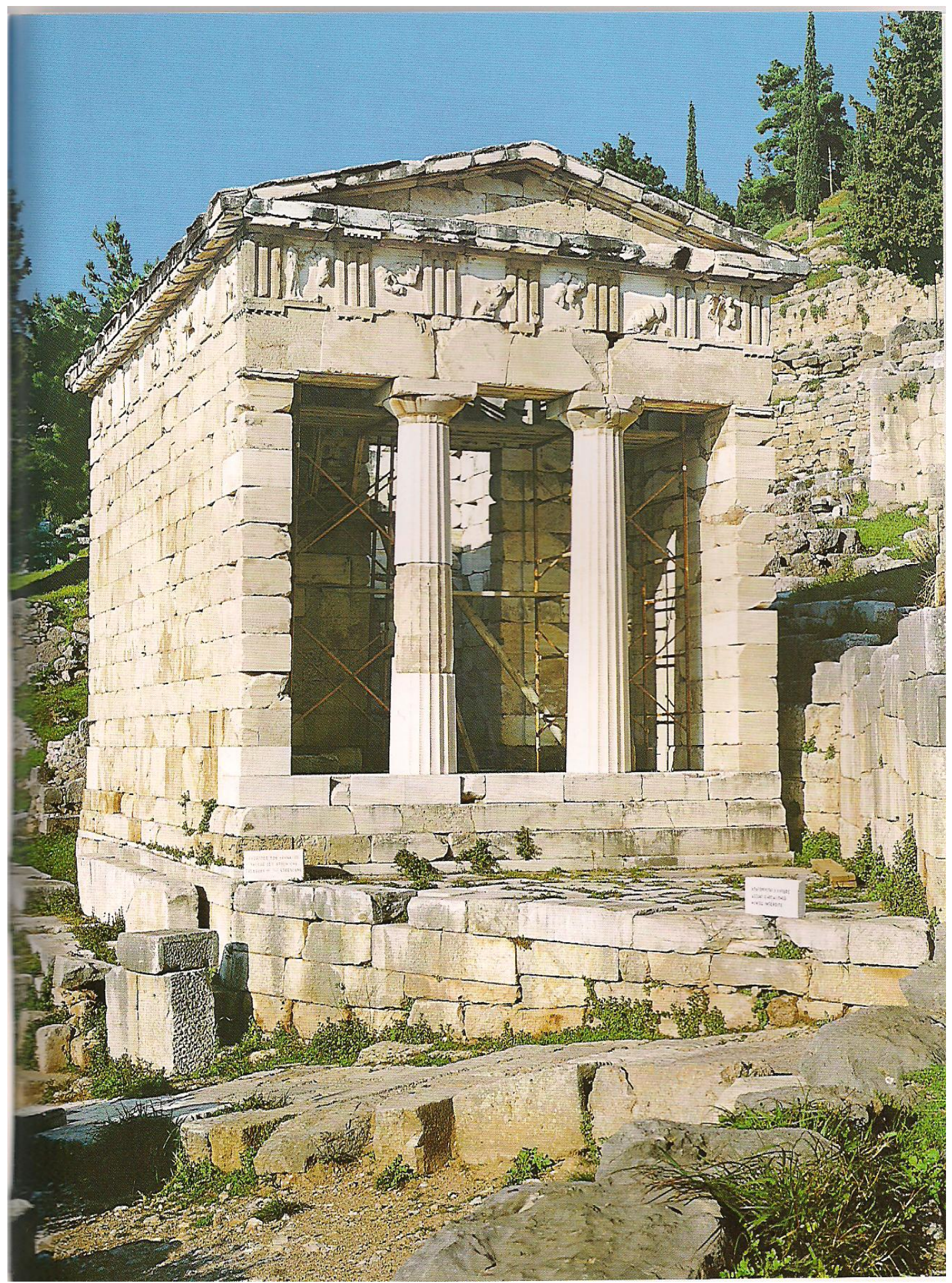

\section{Illustrasie 2: Ruïne van die Atheense skatkamer (Petsas, 2008:43).}

Idelsohn se navorsing toon verbasende ooreenkoms aan tussen die sinagoge-musiek van verskillende afgeleë, geïsoleerde Joodse nedersettings in die Ooste, soos byvoorbeeld die Jode in Jemen, en die Georgiaanse Jode in Transkaukasië meer as duisend myl daarvandaan, asook in die sinagoge-musiek van die ouer Babiloniese en Persiese gemeenskappe (Sendrey \& Norton 1964:265). Selfs Noord-Afrika word betrek wanneer Idelsohn die melodieë van die Marokkaanse Jode insluit. Ten spyte van eeuelange gebrek aan kontak met mekaar het hy bevind dat daar tog 
ooreenkomstige melodieë en selfs volledige ooreenkomstige liedtipes in die liturgiese gesange aangetref word. Die nog bestaande liedere en kantillering van die Oosterse Jode mag moontlik volgens Sendrey en Norton 'n direkte skakel met die Psalms van antieke Israel wees (1964:266).

Die melodiese openingsfiguur wat gekies word om die terugsporing van melodiese spore te demonstreer, is die sprong van trap 1 na trap 5 van die toonleer aangesien trap 5 as resiteertoon 'n belangrike rol gespeel het in die Gregoriaanse cantus planus-repertorium van die Middeleeue (Bailey 2001:454). 'n Hele aantal Middeleeuse melodieë begin volgens Richard Hoppin met 'n dramatiese opwaartse sprong van 'n kwint (1978:75). Indien 'n derde noot ook verreken word, word 'n meer volledige musikale gestalte betrek. Die prominentste drienootfigure wat so gevorm word, word deur toonleertrappe 1-5-6, 1-5-4 en 1-5-3 voorgestel.

\section{Toonleertrappe 1-5-6}

Die bekende fugatema van Bach in C mineur (BWV 537) ${ }^{23}$ begin met hierdie drienootfiguur. Die herhaling van trap 5 herinner aan die resiteertoon van die Gregoriaanse cantus planus.

\section{Voorbeeld 3a: Bach, Prelude en Fuga in c, BWV 537, fugatema, mate 1-4}

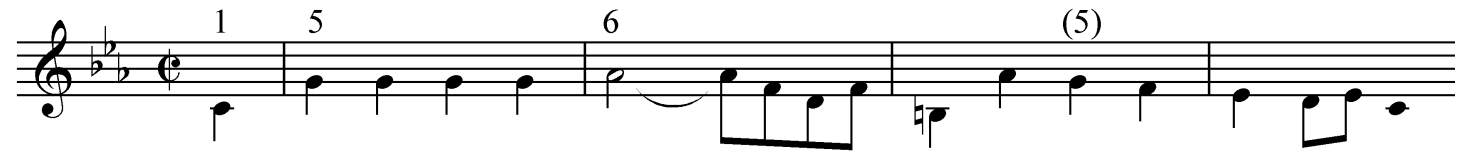

Die Geneefse Psalm 19,24 die Duitse koraal Freut euch, ihr lieben Christen all ${ }^{25}$ asook die daaropvolgende Middeleeuse melodie Puer natus est ${ }^{26}$ en Joodse melodie no $41^{27}$ begin met hierdie melodiese gestalte.

\section{Voorbeeld 3b: Geneefse Psalm 19}

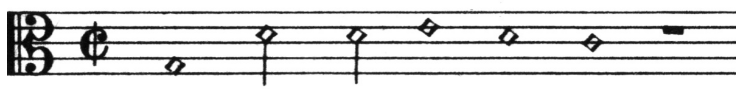

1. Les cieulx en chascun lieu

\section{Voorbeeld 3c: Freut euch, ihr lieben Christen all}

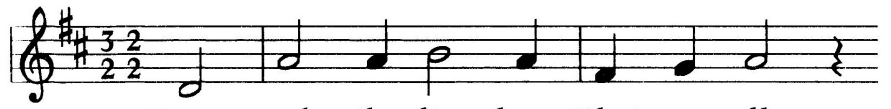

I. Freut euch, ihr lie - ben Chri-sten all, 


\section{Voorbeeld 3d: Puer natus est}

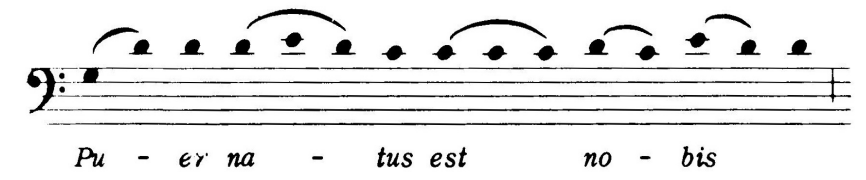

Voorbeeld 3e: Joodse melodie no. 41

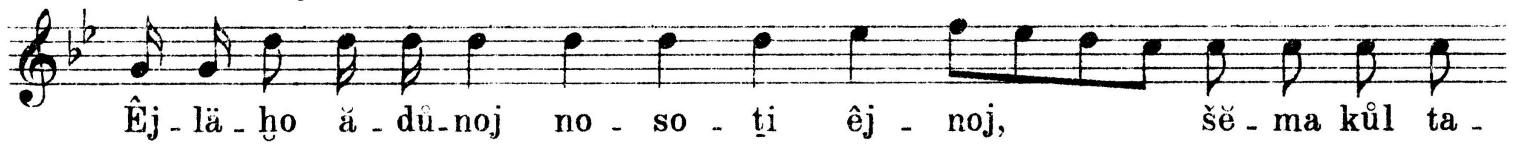

\section{Toonleertrappe 1-5-4}

Die openingspatroon met toonleertrappe 1-5-4 kom voor aan die begin van Buxtehude se tweede fugale gedeelte uit die Prelude in G mineur, BuxWV 163. Hier herinner die herhaalde note ook aan die Gregoriaanse cantus planus met sy resiteertoon op trap 5.

\section{Voorbeeld 4a: Prelude in g, BuxWV 163, fugatema, mate 44-6}

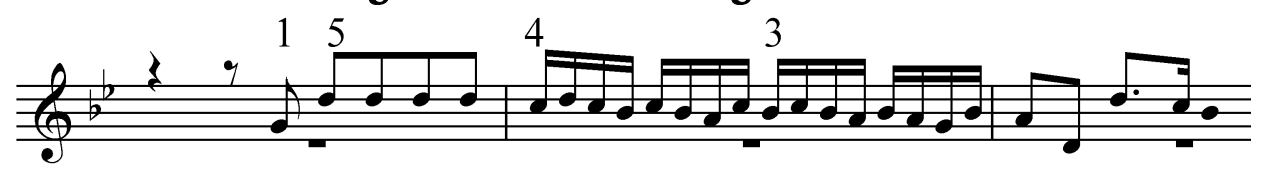

Die Geneefse Psalm 84, ${ }^{28}$ die daaropvolgende Middeleeuse Kerslied Deus pater filium suum $^{29}$ en 'n Joodse melodie ${ }^{30}$ begin met toonleertrappe 1-5-4.

\section{Voorbeeld 4b: Geneefse Psalm 84}

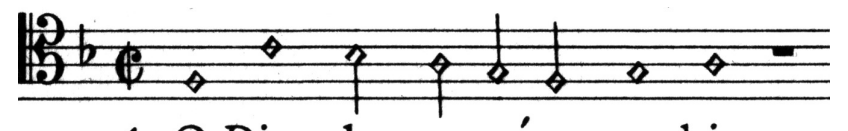

1. O Dieu des armées combien

\section{Voorbeeld 4c: Tropus Deus pater filium suum}

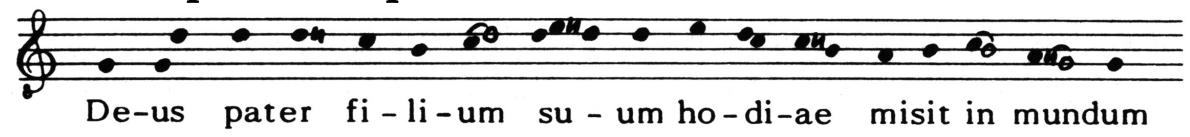

28 Uit Pidoux (1962:83).

29 Uit Hiley (1997:222).

$30 \quad$ Uit Idelsohn (1922a:126). 
Voorbeeld 4d: Joodse melodie no. 154

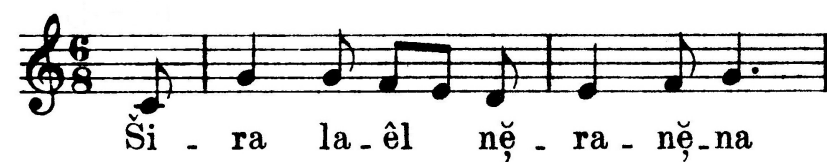

Toonleertrappe 1-5-3

Voorbeelde $4 \mathrm{a}$ tot $4 \mathrm{~d}$ begin met trappe 1-5-4-3 van die toonleer. Die weglating van trap 4 het 'n drieklankformasie tot gevolg. Trappe 1-5-3 kom voor aan die begin van die ostinaatpatroon van Bach se bekende Passacaglia in $\mathrm{C}$ mineur ${ }^{31}$ en aan die begin van die Geneefse Ps $24 .{ }^{32}$

Voorbeeld 5a: Bach, Passacaglia in c, BWV 582

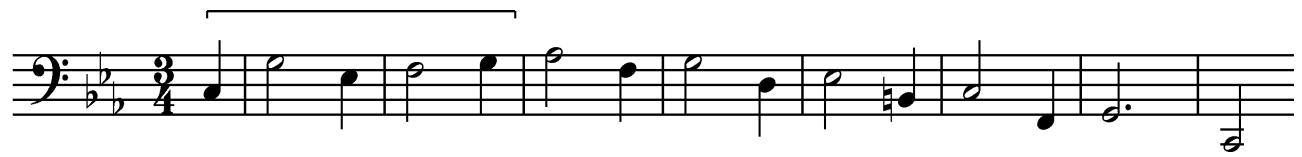

Voorbeeld 5b: Psalm 24

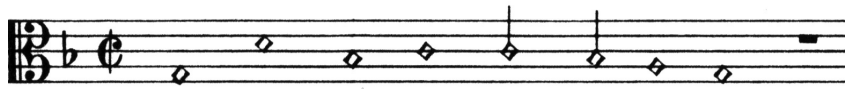

1. La terre au Seigneur appartient,

Die melodiese gestalte wat gevorm word deur die eerste vyf note van Bach se Passacaglia-tema (met hakie in vb. 5a gemerk), kan sover teruggespoor word as die eerste eeue n.C., naamlik die Grafskrifvan Seikilos se opening. ${ }^{33}$

\section{Voorbeeld 5c: Grafskrif van Seikilos}

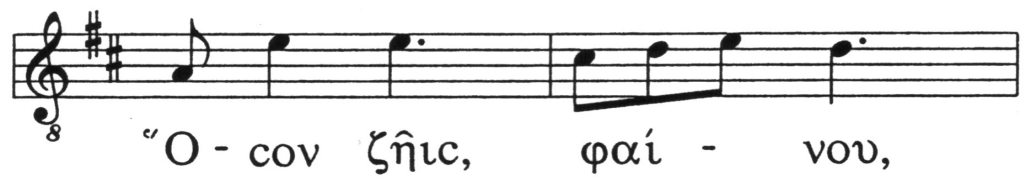

\footnotetext{
$31 \quad$ Uit Bach (1984).

32 Uit Pidoux (1962:33).

33 Burkholder et al. (2010:19).
} 
Volgens John Landels is hierdie die vroegste mees volledige musiekstuk wat behoue gebly het (1999:252). ${ }^{34}$ Hoewel daar twyfel oor die ontstaandatum is, beskou hy die eerste eeu n.C. as die waarskynlikste ontstaantyd. Pöhlmann en West (2001:70) gee die ontstaandatum egter aan as die tweede eeu n.C., en klassifiseer dit onder die Romeinse periode. Hierdie grafskrif is gegraveer op 'n grafsteen, in die vorm van 'n ronde pilaar (Comotti 1989:114).

Volgens Terence Bailey is die derde trap van die toonleer, benewens trap 5, die ander belangrike resiteertoon in Gregoriaanse cantus plani (2001:454). Indien die melodiese figuur wat gevorm word deur die sprong van trap 1 na trap 3 op dieselfde manier in die verlede teruggespoor word, kan melodiese spore teruggevoer word tot by twee gerestoureerde Delfiese himnes uit die antieke Griekse beskawing. ${ }^{35}$ Hierdie twee liedere begin albei met die opwaartse sprong van 'n derde.

Hierdie Delfiese himnes verteenwoordig volgens Landels die vroegste musiekkomposisies uit antieke Griekeland wat in taamlike substansiële ${ }^{36}$ fragmente behoue gebly het (1999:218). Delphi is beskou as die spirituele sentrum van die antieke Griekse beskawing. Daar is lank aanvaar dat die eerste Delfiese himne uit 138 v.C. en die tweede uit 128 v.C. dateer, maar 'n onlangse studie het aangetoon dat hulle albei geskryf is om in $128 / 7$ v.C. by die Pythiese spele uitgevoer te word (Pöhlmann \& West 2001:71). ${ }^{37}$ Benewens atletiek het die Pythiese spele ook teater- en musiekkompetisies ingesluit. Op die vierde dag is tragedies en komedies asook himnes aan Apollo met begeleiding op die kitara (lier) uitgevoer (Petsas 2008:14).

Albei die Delfiese himnes is bewaar as steengraverings op die suidelike muur van die Atheense skatkamer in Delphi (Pöhlmann 1995:1639). Die steenblokke met graverings is in 1893 deur Franse argeoloë in die ruïnes van die skatkamer gevind (Landels 1999:222). Later is die beskadigde gegraveerde steenblokke wat die himnes bevat op 'n marmerblad gemonteer wat tans in die Delphi Museum uitgestal word.

Die tekens wat die melodie en die begeleiding voorstel, is deur twee Duitse navorsers Fr. Bellermann en K. Fortlage ontsyfer (Petsas 2008:100). ${ }^{38}$ Volgens Pöhlmann en West het die beskadiging en verbrokkeling van die steenblokke, veral aan die kante, veroorsaak dat die volledige teks met moeite akkuraat ontsyfer kan word (2001:70).

Die opening van die tweede Delfiese himne wat deur Limenios gekomponeer is, word hier gebruik omdat dit meer volledig is as die eerste himne. Slegs die eerste noot ontbreek in Pöhlmann en West se weergawe (2001:75) maar Landels het die noot ingevul na analogie van die openingsmateriaal wat in die loop van die himne terugkeer (1999:236-43). Die openingsmotief

Die vroegste fragmente van antieke Griekse tekste met musieknotasie stam volgens Pöhlmann en West egter uit die vyfde eeu v.C. (2001:8-11). Die afgelope dekades het 'n hele paar nuwe ontdekkings van outentieke musiekfragmente opgelewer, sodat die aantal oorgelewerde tekste volgens Pöhlmann en West gedurende die afgelope dertig jaar vanaf 35 tot 61 aangegroei het (2001:6). Bespreek deur Van Rensburg (2010:179-88).

Die eerste Delfiese himne, soos in moderne notasie weergegee, beslaan 126 mate (Pöhlmann \& West 2001:63, 65-9), en die tweede Delfiese himne 174 mate (Pöhlmann \& West 2001:75-81).

Aangesien die Griekse kalenderjaar in Junie begin, word die formaat 128/7 v.C. gebruik (Landels 1999:221).

Die Griekse toonleersisteem stem nie presies ooreen met die sisteem wat ons tans gebruik nie omdat die groottes van half- en heeltone nie presies met die huidige sisteem ooreenkom nie (Landels 1999:214-7). Dit het sekere implikasies wat transkripsie betref (Landels 1999:226-8) maar die geringe afwykings van huidige toonhoogtes beïnvloed nie die gestaltes van die temas nie. 
van die tweede Delfiese himne bestaan uit 'n derdesprong wat weer eens deur herhaalde note gevolg word. $^{39}$

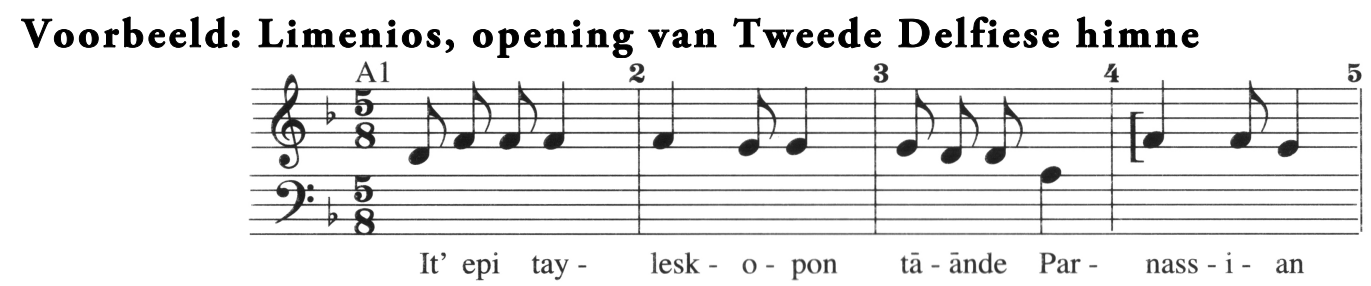

\section{Ten slotte}

Hoewel dit nie die doel van hierdie artikel was om 'n deurlopende historiese lyn ten opsigte van melodiese spore aan te toon nie, het die historiese perspektief wel uitgewys dat uitsprake oor beïnvloeding en ontlening op die gebied van melodie nie maklik gemaak kan word nie. Die saak word verder gekompliseer wanneer oorgelewerde melodiese spore deel vorm van 'n soort musiekwoordeskat wat algemeen beskikbaar is. Dit is egter onmoontlik om in die beperkte formaat van 'n tydskrifartikel reg te laat geskied aan so 'n omvangryke saak soos musikale ontlening en die esteties-artistieke en die etiese implikasies daarvan. Hierdie bydrae moet dus gesien word as ' $\mathrm{n}$ basiese poging om aan te toon hoe kompleks die saak is en dat 'n deegliker besinning noodsaaklik is voordat simplistiese uitsprake en reduksionistiese veralgemenings oor ontlening en beïnvloeding gemaak kan word.

Verder kan 'n sensitiwiteit vir melodiese openingsgestaltes die luisteraar help om die temporele ontplooiing van die musiek te volg omdat hoof tematiese idees meestal in die loop van 'n werk voorkom. Indien Agawu se stelling aanvaar word, naamlik dat die identifisering van betekenisvolle eenhede in ' $n$ komposisie die eerste stap is in die proses om sin te maak van musiek (1999:149), kan so 'n sensitiwiteit vir melodiese openingsgestaltes 'n mens dus ook help om musiek beter te verstaan.

\section{Bibliografie}

Agawu, K. 1999. The challenge of semiotics. In Cook, N. \& Everist, M. (eds). Rethinking music. Oxford: Oxford University Press.

Agawu, K. 2003. Representing African music: postcolonial notes, queries, positions. New York: Routledge.

Apel, W. 1972. The history of early keyboard music. Uit Duits vertaal en hersien deur Hans Tischler. Indiana: Indiana University Press. 
Bach, J.S. 1964. Neue Ausgabe sämtlicher Werke. Serie IV: Orgelwerke Band 6. Kassel: Bärenreiter.

Bach, J.S. 1972. Neue Ausgabe sämtlicher Werke. Serie IV: Orgelwerke Band 5. Kassel: Bärenreiter.

Bach, J.S. 1984. Neue Ausgabe sämtlicher Werke. Serie IV: Orgelwerke Band 7. Kassel: Bärenreiter.

Bailey, T. 2001. Psalm: Latin monophonic psalmody. In Sadie, S. (ed). The new Grove dictionary of music and musicians. Vol. 20. London: Macmillan.

Braun, J. 1996. Jüdische Musik: Einleitung; Altisrael; Mittelalter. In Finscher, L. (Hrsg). Die Musik in Geschichte und Gegenwart. Kassel: Bärenreiter. Vol. 4.

Brown, H.M. 1982. Emulation, competition, and homage: imitation and theories of imitation in the Renaissance. Journal of the American musicological society, 35:1-48, Spring.

Burkholder, J.P. 1994. The uses of existing music: musical borrowing as a field. Notes, 50(3):851-70.

Burkholder, J.P. 1995. All made of tunes: Charles Ives and the uses of musical borrowing. New Haven: Yale University Press.

Burkholder, J.P. 2001. Borrowing. In Sadie, S. (ed). The new dictionary of music and musicians. Vol. 4. London: Macmillan.

Burkholder, J.P. (ed). 2003. Musical borrowing: an annotated bibliography. http://www.music.indiana.edu/borrowing/browseab.html [5 Okt. 2009].

Burkholder, J.P., Grout, D.J. \& Palisca, C.V. 2006. A history of western music. 7e uitgawe. New York: W.W. Norton.

Burkholder, J.P., Grout, D.J. \& Palisca, C.V. 2010. A history of western music. 8e uitgawe. New York: W.W. Norton.

Burmeister, J. 1606 [1993]. Musica Poetica [Musical Poetics], uit Duits vertaal deur B. V. Rivera. New Haven: Yale University Press.

Butcher, S.H. 1951. Aristotle's theory of poetry and fine arts: with a critical text and translation of The poetics. New York: Dover Publications.

Buxtehude, D. 1997. Sämtliche Orgelwerke. Geredigeer deur Klaus Beckmann. 2 vols. Wiesbaden: Breitkopf \& Härtel.

Chew, G. \& McKinnon, J.W. 2001. Centonization. In Sadie, S., ed. New Grove dictionary of music and musicians. Vol 5. London: Macmillan.

Clark, R. \& Peterson J.D. (eds). 1984. Johann Sebastian Bach: Orgelbüchlein, with introduction, figured-bass chorales, texts, and commentary. St. Louis, Mo.: Concordia.

Cloete, H. 2009. Skrywers kap mekaar oor 'plagiaat'. Rapport, 20 Desember.

Collins, M. \& Carter, S.A. 2001. Improvisation: The Baroque period (i) \& (ii). In Sadie, S. (ed). The new Grove dictionary of music and musicians. Vol. 12. London: Macmillan. 
Comotti, G. 1989. Music in Greek and Roman culture. Uit Italiaans vertaal deur Rosaria V. Munson. Baltimore: Johns Hopkins University Press.

Dobszay, L. 2007. Two paradigms of orality: the office and the mass. Hants: Ashgate.

Elias, C.A. 2004. Mid-sixteenth-century chanson masses: a kaleidoscopic process. In Meconi, H. (ed). Early musical borrowing. New York: Routledge.

Evangelisches Gesangbuch. 1994. Bremen: Verlagsgemeinschaft für das Evangelische Gesangbuch Niedersachsen.

Fornaçon, S. 1958. Psalm 42 aus Genf. Jahrbuch für Liturgik und Hymnologie, 4:111-4.

Greenblatt, S. 1995. Culture. In Lentricchia, F. \& McLaughlin, T. (eds). Critical terms for literary study. Chicago: The University of Chicago Press.

Gruber, G. 1998. Zitat. In Finscher, L. (Hrsg). Die Musik in Geschichte und Gegenwart. Vol. 9. Kassel: Bärenreiter.

Harnoncourt, N. 1982. Musik als Klangrede. Uit Duits vertaal deur Mary O’Neill. Portland, OR: Amadeus Press.

Harris, E.T. 1990. Integrity and improvisation in the music of Handel. Journal of musicology, 8:301-15.

Hiley, D. 1997. Western plainchant: a handbook. Oxford: Clarendon Press.

Hoppin, R.H. 1978. Medieval music. New York: W.W. Norton.

Horsley, I. 2001. Improvisation: Western art music: History to 1600. In Sadie, S. (ed). The new dictionary of music and musicians. Vol. 12. London: Macmillan.

Idelsohn, A.Z. 1922a. Hebräisch-Orientalischer Melodienschatz: Gesänge der Babylonischen Juden. Jerusalem: Benjamin Harz Verlag.

Idelsohn, A.Z. 1922b. Hebräisch-Orientalischer Melodienschatz: Gesänge der Persischen, Bucharischen und Daghestanischen Juden. Jerusalem: Benjamin Harz Verlag.

Jones, R. D. P. 2007. The creative development of Johann Sebastian Bach, vol. 1, 1695-1717. New York: Oxford University Press.

Jost, W. \& Hyde, M.J. (eds). 1997. Rhetoric and hermeneutics in our time: a reader. New Haven: Yale University Press.

Klatzow, P. 1994. To the editor. South African journal of musicology, vol. 14:125-6.

Klusen, E. 1958. Gregorianischer Choral und frühprotestantisches Kirchenlied: neue Gesichtspunkte zur Beurteilung ihrer gegenseitigen Beziehung. In Abraham, G., Clercx-Lejeune, S., Federhofer, H. \& Pfannkuch, W., (Hrsgs). Bericht über den siebenten internationalen musikwissenschaftlichen Kongress Köln. Kassel: Bärenreiter.

Kramer, L. 2002. Musical meaning: toward a critical history. Berkeley, Calif.: University of California Press.

Landels, J.G. 1999. Music in ancient Greece and Rome. London: Routledge.

Liedboek. 2001. Liedboek van die kerk. Kaapstad: NG Kerk-Uitgewers.

Lucia, C. 1993. Reviews of scores: Klatzow, Peter, From the poets. South African journal of musicology, vol. 13:114-7. 
Meconi, H. (ed). 2004. Early musical borrowing. New York: Routledge.

Muller, S. \& Walton, C. (eds). 2006. A composer in Africa: essays on the life and work of Stefans Grové. Stellenbosch: Sun Press.

Murphy, J.J. 1996. Quintilian. In Enos, T. (ed). Encyclopedia of rhetoric and composition: communication from ancient times to the information age. New York: Garland.

Newman, A. 1985. Bach and the Baroque. New York: Pendragon Press.

Petsas, P.M. 2008. Delphi: Denkmäler und Museum. Athene: Krene.

Picker, M. 2001. Contrafactum: Before 1450. In Sadie, S. (ed). The new Grove dictionary of music and musicians. Vol. 20. London: Macmillan.

Pidoux, P. 1955. Über die Herkunft der Melodien des Hugenotten-Psalters. Jahrbuch für Liturgik und Hymnologie, 1:113-4.

Pidoux, P. 1956. Untersuchungen zu den Aulcuns Pseaumes et Cantiques mys en chant à Strasbourg 1539 (I). Jahrbuch für Liturgik und Hymnologie, 2:107-9.

Pidoux, P. 1962. Le Psautier Huguenot du XVIe siècle. Basel: Bärenreiter.

Pöhlmann, E. 1995. Griechenland: Antike Musik. In Finscher, L. (Hrsg). Die Musik in Geschichte und Gegenwart. Vol. 3. Kassel: Bärenreiter.

Pöhlmann, E. \& West, M.L. 2001. Documents of Ancient Greek music. Oxford: Clarenden Press.

Psalmboek. 2003. Die berymde en omgedigte Psalms en ander Skrifberyminge in gebruik by die Gereformeerde Kerke in Suid-Afrika. Wellington: NG Kerk-Uitgewers.

Reynolds, C. 2004. Interpreting and dating Josquin's Missa Hercules dux ferrariae. In Meconi, H. (ed). Early musical borrowing. New York: Routledge.

Schleifer, E. 2001. Jewish music: Synagogue music and its development. In Sadie, S. (ed). The new Grove dictionary of music and musicians. Vol. 13. London: Macmillan.

Sendrey, A. \& Norton, M. 1964. David's harp: the story of music in biblical times. New York: NAL-World.

Slenk, H. \& Luth, J.R. 2001. Psalms, metrical: the European continent. In Sadie, S. (ed). The new Grove dictionary of music and musicians. Vol. 20. London: Macmillan.

Spies, B.M. 2011. Tematiese fisionomie skep toegang tot drie uiteenlopende 20e-eeuse komposisies. LitNet Akademies Jaargang 8:2, https://www.givengain. com/cgibin/giga.cgi?cmd=cause_dir_news_item\&news_id=107089\&cause_id=1270.

Tempelhoff, J. 2002. Verhuidiglikte verlede - aspekte van die hermeneutiese verstaansmetode in geskiedenis. Vanderbijlpark: Kleio.

Van Rensburg, H. 2010. 'n Historiese perspektief op musikale ontlening met spesifieke verwysing na tematiek in die vrye orrelwerke van Buxtehude en Bach. PhD-proefskrif. Potchefstroom: Noordwes-Universiteit.

Wagner, P. 1986. Introduction to the Gregorian melodies: a handbook of plainsong, part I: Origin and development of the forms of the liturgical chant up to the end of the Middle Ages. New York: Da Capo Press. 
Walton, C. 2006. Connect, only connect: Stefans Grové's road from Bethlehem to Damascus. In Muller, S. \& Walton, C. (eds). A composer in Africa: essays on the life and work of Stefans Grové. Stellenbosch: Sun Press.

Yasser, J. 1969. The opening theme of Rachmaninoff's third piano concerto and its liturgical prototype. Musical quarterly, 55:317-24.

Zimmerman, F.B. 1966. Musical borrowings in the English Baroque. Musical quarterly, 52:483-95, Oct. 